\title{
Two newly recorded dragonfly species (Odonata: Libellulidae) for the Novosibirskaya Oblast of Russia
}

\section{Ава вида стрекоз (Odonata: Libellulidae) впервые найдены в Новосибирской области России}

\author{
O.E. Kosterin*, V.V. Onishko** \\ О.Э. Костерин *, В.В. Онишко **
}

\begin{abstract}
* Institute of Cytology \& Genetics SB RAS, Academica Lavrentyeva Ave. 10, Novosibirsk 630090 Russia; Novosibirsk State University, Pirogova Str. 2, Novosibirsk630090 Russia. E-mail: kosterin@bionet.nsc.ru.

* Институт цитологии и генетики СО РАН, пр. Академика Лаврентьева 10, Новосибирск 630090 Россия; Новосибирский Национальный Исследовательский Университет, ул. Пирогова 2, Новосибирск 630090 Россия.

** GAU Moscow Zoo, Department of Herpetology, Bolshaya Gruzinskaya Str. 1, Moscow 123242 Russia.

** ГАУ Московский зоопарк, отдел герпетологии, ул. Большая Грузинская 1, Москва 123242 Россия.
\end{abstract}

Key words: Odonata, dragonflies, Orthetrum brunneum, Sympetrum depressiusculum, West Siberia, Novosibirsk Oblast', first record, water pollution.

Ключевые слова: Odonata, стрекозы, Orthetrum brunneum, Sympetrum depressiusculum, Западная Сибирь, Новосибирская область, первая находка, загрязнение воды.

Abstract. In 2020, Orthetrum brunneum (Fonscolombe, 1837) and Sympetrum depressiusculum (Selys, 1841) were first recorded for Novosibirskaya Oblast as photographic observations in the iNaturalist internet platform. Their populations and habitats were examined in situ. The habitat of O. brunneum at the Eltsovka Vtoraya River in Zaeltsovksiy Park in Novosibirsk lacked other lotic Odonata as a result of pollution. Supposedly the river inside the city limits is warm enough during winter to make possible its colonisation by $O$. brunneum far to the north of its main range. The record of S. depressiusculum (Selys, 1841) at the Obskoe Water Reservoir is the northernmost in Siberia. A list of 57 Odonata species currently known from Novosibirskaya Oblast is also provided.

Резюме. В 2020 г. Orthetrum brunneum (Fonscolombe, 1837) и Sympetrum depressiusculum (Selys, 1841) были впервые отмечены в Новосибирской области в виде фотографических наблюдений на интернет-платформе iNaturalist. Их популяции и местообитания были затем обследованы на месте. Популяция $O$. brunneum обитает в Заельцовском парке Новосибирска на речке Ельцовка 2я, ниже по течению от её участка длиной 9 км, протекающего через город. Её вода загрязнена и потому лишена иных реофильных видов стрекоз и, возможно, подогрета в зимнее время, что по всей видимости и позволило O. brunneum колонизировать это местообитание столь далеко к северу от его основного ареала. Находка $S$. depressiusculum (Selys, 1841) на Обском водохранилище - также самая северная в Сибири. Приведён список из 57 видов стрекоз, на данный момент известных из Новосибирской области.

\section{Introduction}

The fauna of dragonflies (Odonata) of Novosibirskaya Oblast (Novosibirsk Province) is well studied because the team of odonatologists, founded by
B.F. Belyshev in 1950s and having been working until present, is based in Novosibirsk at the Institute of Systematics and Ecology of Animals of the Siberian Branch of the Russian Academy of Sciences (formerly Biological Institute) [Haritonov et al., 2007; Haritonov, 2010]. Some areas attracted focused attention: the Karasuk Station of the above mentioned institute, situated in the steppe zone at Troitskoe village of Karasuk District [Zaika, 1974; Borisov, 2005; Borisov et al., 2012] and Novosibirsk Academy Town, being an isolated part of Novosibirsk City embracing neraly undisturbed natural habitats of the eastern forest-steppe and pine forests at the Ob' River [Kosterin 2007, 2013, 2020]. Kosterin et al. [2001] first summarised the fauna of the eastern part of the province bordered by the $\mathrm{Ob}$ ' River to include 48 species. This figure did not contain two species, which to that moment had been found only in the western part of the province: Lestes macrostigma (Eversmann, 1836) [Zaika, 1974] and Aeshna caerulea (Ström, 1783) [Belyshev, 1973]. The latter report was rather dubious as being two dots immediately to the north and to the south of Lake Chany and the mention of the northern Barabinskaya forest-steppe in the monograph by Belyshev [1973], without published details. No further records of that taigous species in Novosibirskaya Oblast appeared since that. Popova \& Haritonov [2012] updated the provincial fauna with Coenagrion ecornutum (Selys, 1872) and Orthetrum cancellatum (Linnaeus, 1758), Kosterin [2013] with Ischnura pumilio (Charpentier, 1825), Popova, Eremina [2016] with Sympetrum fonscolombii (Selys, 1840). Kosterin [2015] summarised the Odonata fauna of the territory of Novosibirsk City to include 50 species but Lestes barbarus (Fabricius, 1798) was included in error. Kosterin [2020] updated the fauna of the city limits with C. ecornutum, Aesh- 

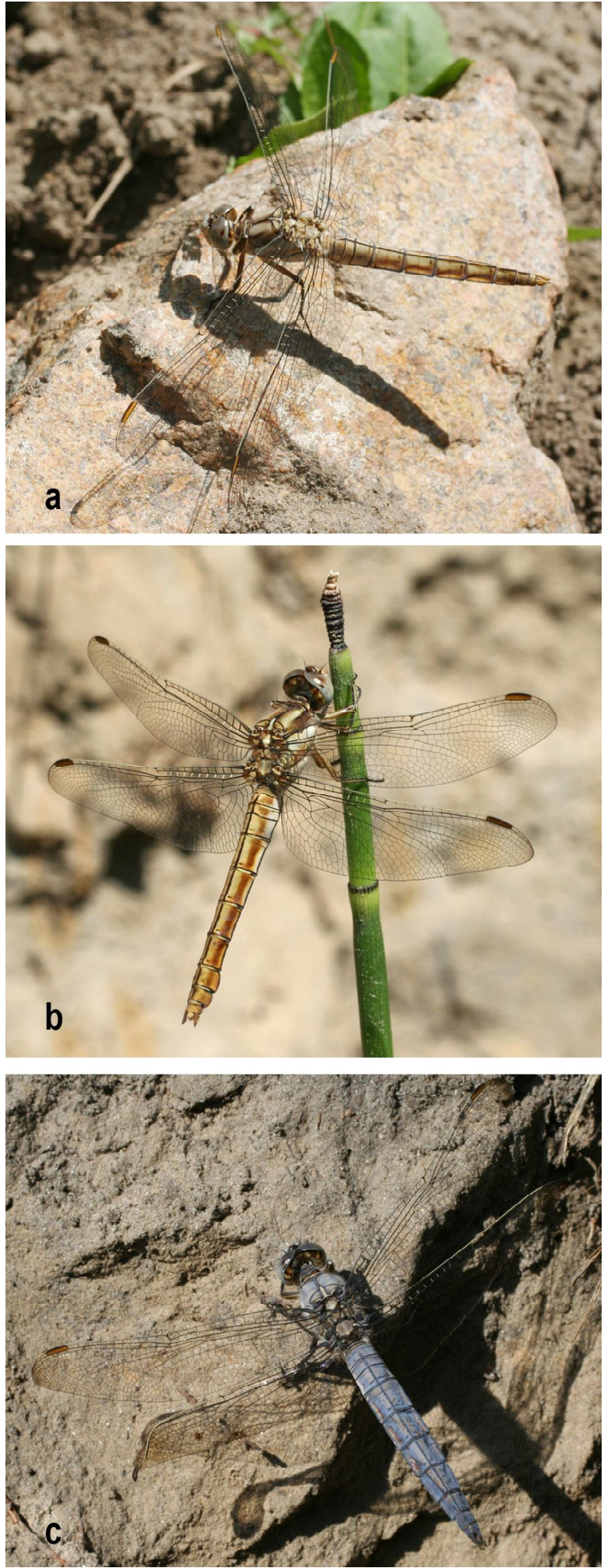

Fig. 1. Orthetrum brunneum at the El'tsovka $2^{\text {nd }}$ Rivulet valley just upstream of the pipeline bridge, Zayel'tsovskiy Park, in Novosibirsk, 7.07.2020: a - immature male; b - female; c semimature male. Photo by O. Kosterin.

Рис. 1. Orthetrum brunneum у р. Ельцовка 2я сразу выше моста трубопровода, Заельцовский парк в Новосибирске, 7.07.2020: a - молодой самец; b - самка; c - полузрелый самец. Фото О. Костерина. na subarctica Walker, 1908 and Somatochlora exuberata Bartenev, 1910, the latter species (hitherto considered not to occur westerly of Central Siberia) being new for the Novosibirsaya Oblast. To the end of 2019 the known fauna of dragonflies and damselflies of Novosibirskaya Oblast counted 55 species and that of the Novosibirsk City territory -52 species.

\section{Materials and Methods}

Since dragonflies are large and colourful creatures, many their species can be reliably identified by photographs. In order to collect 'citizen science' data on dragonfly distribution from numerous amateour naturalists of our country, we utilised the popular internet platform iNaturalist [2021]. In April 2020, the second author launched there the collection project Dragonflies of Russia (2021), later converted to an umbrella project combining data from regional projects launched for all subjects of Russian Federation. The 'research grade' (confirmed by other users) iNaturalist observations are adopted by Global Biodiversity Informational Facility (GBIF) and are traditionally referenced in scientific literature as a whole (with a single DOI index) as Ueda [2021]. In 2020 this way of collecting information yielded two dragonfly species new for Novosibirskaya Oblast. The first author then examined in situ the exact habitat of one of them, and found the other species in a habitat close to that recorded in iNaturalist. All photographic records are geo-tagged; the coordinates are provided below in the decimal degree format, with the precision of four digits after decimal point.

\section{Results}

\section{Orthetrum brunneum (Fonscolombe, 1837)} Fig. 1.

Material. Novosibirsk, Zayel'tsovskiy Park, the El'tsovka $2^{\text {nd }}$ Rivulet valley just upstream of the pipeline bridge, 55.057 $\mathrm{N}, 82.871 \mathrm{E}, 7.07 .2020$, O. Kosterin - $20^{7} \mathrm{O}^{7}$ (immature), 3 우 (in the Institute of Systematics and Ecology of Animals of the Siberian Branch of the Russian Academy of Sciences (ISEA further in the text) and the first author's collection).

Pbotograpbic data in iNaturalist (2021) (identification numbers for specific observations are given in parenthesis): Novosibirsk, Zayel'tsovskiy Park, the El'tsovka $2^{\text {nd }}$ Rivulet valley, $55.0594^{\circ} \mathrm{N}, 82.8702^{\circ} \mathrm{E}, 1.07 .2020$, I. Sukhov - 19 $(51565830,51565839)$; the same place, $55.0628^{\circ} \mathrm{N}$, $82.8708^{\circ}$ E, 1.07.2020, I. Sukhov - 1 \% (51566851); the same place, $55.0600^{\circ} \mathrm{N}, 82.8714^{\circ} \mathrm{E}, 5.07 .2020$, D. Zhbir $-10^{7}$ (mature) (51997093); the same place, $55.0571^{\circ} \mathrm{N}, 82.8711^{\circ} \mathrm{E}$, 7.07.2020, O. Kosterin - $10^{7}$ (immature), 1 우 (52383679, $52383777)$; the same place, $55.0575^{\circ} \mathrm{N}, 82.8712^{\circ} \mathrm{E}, 7.07 .2020$, O. Kosterin -1 19 (Fig. 1a) (52386428); the same place, $55.0576^{\circ} \mathrm{N}, 82.8713^{\circ} \mathrm{E}, 7.07 .2020$, O. Kosterin - 1 오 (Fig. 1b) (52387580); the same place, $55.0579^{\circ} \mathrm{N}, 82.8712^{\circ} \mathrm{E}, 7.07 .2020$, O. Kosterin - 10 (semimature) (Fig. 1c) (52427069); the same place, $54.9698^{\circ} \mathrm{N}, 82.8241^{\circ}$ E, 8.07.2020, I. Sukhov $10^{7}$ (mature) (52356477); the same place, $55.0593^{\circ} \mathrm{N}$, $82.8704^{\circ}$ E, 2.08.2020, I. Sukhov - 1우 (55127591). 

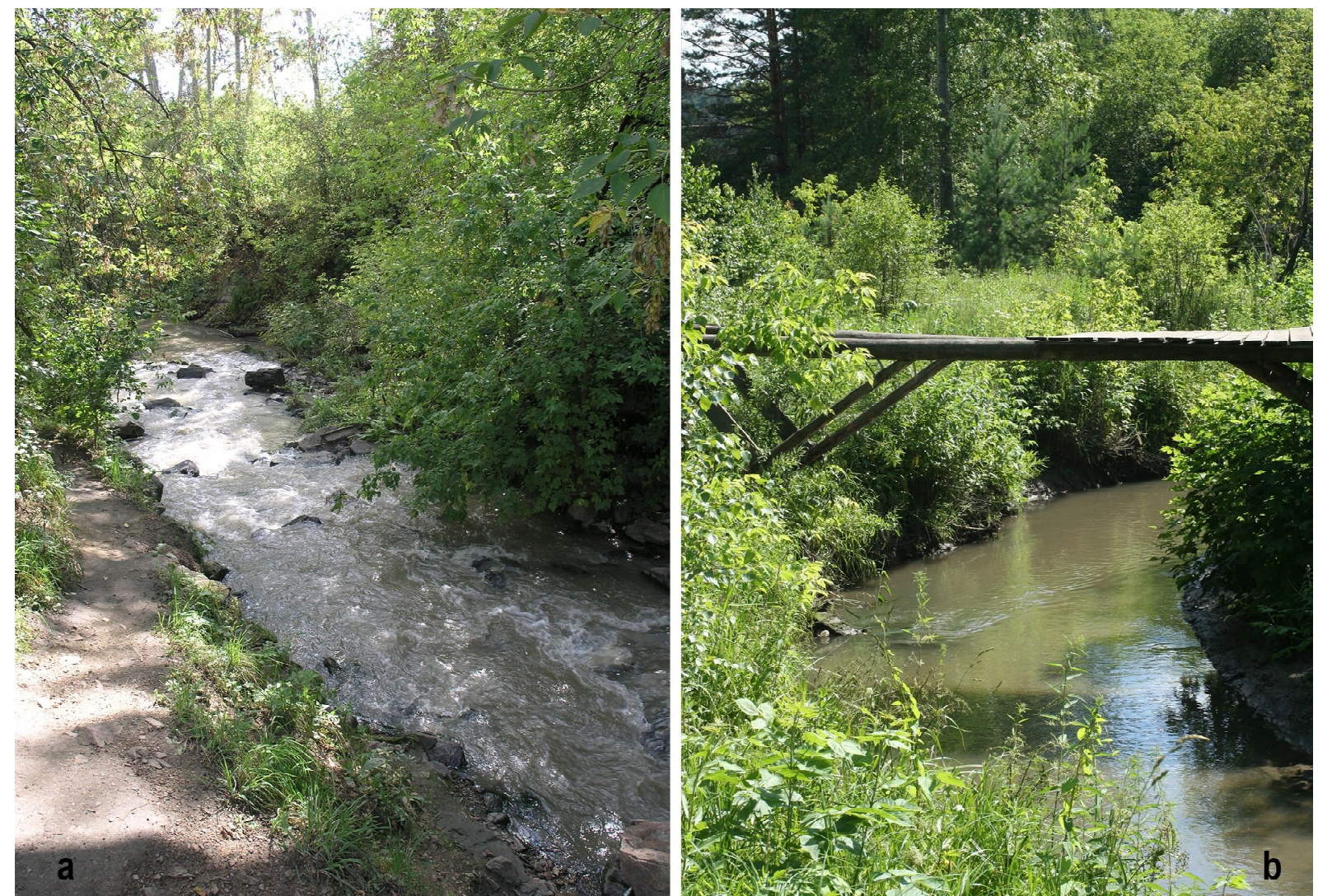

Fig. 2. Habitat of Orthetrum brunneum in Novosibirsk: the El'tsovka $2^{\text {nd }}$ Rivulet valley in Zayel'tsovskiy Park, 7.07.2020: a downstream of the pipeline bridge; $b$ - upstream of the pipeline bridge (not that bridge seen, much bigger). Photo by O. Kosterin.

Рис. 2. Местообитание Orthetrum brunneum в Новосибирске: р. Ельцовка 2я в Заельцовском парке, 7.07.2020: а — ниже моста трубопровода; b - выше моста трубопровода. Фото О. Костерина.

Observations. In 2020, three photographic observations of this species unexpectedly appeared in iNaturalist, made on 1 and 5.07 .2020 by two nature photographers, Ilya Sukhov and Denis Zhbir, in the same locality in Novosibirsk: the El'tsovka $2^{\text {nd }}$ [El'tsovka Vtoraya] Rivulet valley in Zayel'tsovskiy Park. The river flows there in a very narrow valley with a steep and high left border, while the surrounding elevated surfaces are overgrown with pine forest belonging to the broad pine stripe along the Ob' River. Observations by I. Sukhov were made in the floodplain of the El'tsovta $2^{\text {nd }}$ at its both banks, while that by D. Zhbir was made in open pine forest at the brink of the valley left side.

On 7.07.2020 this population was examined by the first author who for one and half hours met in total 9 individuals of O. brunneum on a $200 \mathrm{~m}$ long river stretch: a mature (bue) male, a semimature (scarcely pruinosed) male, two immature (non-pruinosed) males, four females and a teneral (with still glittering wings) female. This result implied that the imagines developed in this river rather than arrived from elsewhere, and their flight period had started not so long ago. The downstream end of the examined river section was marked with a big pipeline crossing the river with a bride, and a ground road along it. The river was fast and even noisy at numerous big stones downstream of the bridge (maybe not natural there) (Fig. 2a), upstream of which its flow was laminar (Fig. 2b). The water was slightly turbid and rather cool. The floodplain was occupied mostly by Betula pendula
Roth, Acer negundo L. and Padus avium Mill. stands of variable density and grassy glades. The imagines preferred open places by the river and perched on dry branches or stems of Equisetum hyemale L. (Fig. 1b). Two females (Fig. 1b) and immature male kept close to a small barren bluff but still perched on stems. A semimature male occupied a small hole in the ground road and sat exclusively to its walls (Fig. 1c). These dragonflies, both immature and mature, were obviously associated with the river. Only one female was found in a small glade by a forest road on the elevated area 90 $\mathrm{m}$ to the east of the river valley. It is noteworthy that no other lotic Odonata were observed at the river, including elsewhere common Calopteryx splendens splendens (Harris, 1780) or Platycnemis pennipes (Pallas, 1771). Only few individuals of Sympetrum sanguineum (Müller, 1764), and $S$. flaveolum (Linnaeus, 1758), omnipresent at dispersal, were observed.

In August, I. Sukhov made the last photographic record of O. brunneum at that place on 2.08.2020, while the first author already did not find it on 28.08.2020. (The aspect of Sympetrum changed: there were $S$. vulgatum vulgatum (Linnaeus, 1758), S. danae (Sulzer, 1776) and, again, S. flaveolum).

In general, all 2020 records of O. brunneum were scattered over a stretch of the Eltsovka $2^{\text {nd }}$ course its crossing by the pipeline bridge to $334 \mathrm{~m}$ upstream of it. This does not imply that the population is actually confined to that short river section but just shows our current knowledge. 
Sympetrum depressiusculum (Selys, 1841) Fig. 3.

Material. Novosibirskaya Oblast: Ordynskoe District, Obskoe Water Reserve NW bank, $1.1 \mathrm{~km} \mathrm{NE}$ of the Spirino village outskirts, an inundated stone quarry, $54.148^{\circ} \mathrm{N}$, $81.612^{\circ}$ E, 5.08.2020, O. Kosterin - $110^{\top} 0^{7}$, 7우우. Novosibirsk Academy Town environs, the Obskoe Water Reserve E bank, the Zyryanka Rivulet estuary, $54.819^{\circ} \mathrm{N}, 83.085^{\circ} \mathrm{E}, 21.08 .2020$ O. Kosterin $-20^{7} 0^{7}$ (in ISEA and the first author's collection)

Photographic data in iNaturalist (2021) (identification numbers for specific observations are given in parenthesis): Novosibirskaya Oblast: Ordynskoe District, Karakanskiy Bor pine forest, the Obskoe Water Reserve SE bank at the Glukhaya Rivulet estuary, $54.4374^{\circ} \mathrm{N}, 82.2687^{\circ} \mathrm{E}, 14.08 .2020$, P. Komkov $-10^{7}, 1$ 우 in tandem (Fig. 3) (57228233); almost the same place, $54.4372^{\circ} \mathrm{N}, 82.2694^{\circ} \mathrm{E}, 14.08 .2020$, P. Komkov - 10 (57228253); Ordynskoe District, $1.1 \mathrm{~km}$ $\mathrm{NE}$ of the Spirino village outskirts, an inundated stone quarry, $54.1475^{\circ} \mathrm{N}, 81.6116^{\circ} \mathrm{E}$, O. Kosterin - $10^{7}$ (immature) (91592750); the same place and date, $54.1476^{\circ} \mathrm{N}, 81.6117^{\circ} \mathrm{E}$ O. Kosterin - 1 copula, 1 ㅇ (immature) (91592546, 91593286); the same place and date, $54.1476^{\circ} \mathrm{N}, 81.6118^{\circ} \mathrm{E}, \mathrm{O}$. Kosterin $20^{7} 0^{7}$ (immature), 3우 (2 teneral, 1 immature) (91591821, 91592502, 91592749, 91592902, 91593284); the same place and date, $54.1477^{\circ} \mathrm{N}, 81.6117^{\circ} \mathrm{E}, \mathrm{O}$. Kosterin - 1 ㅇ (immature)

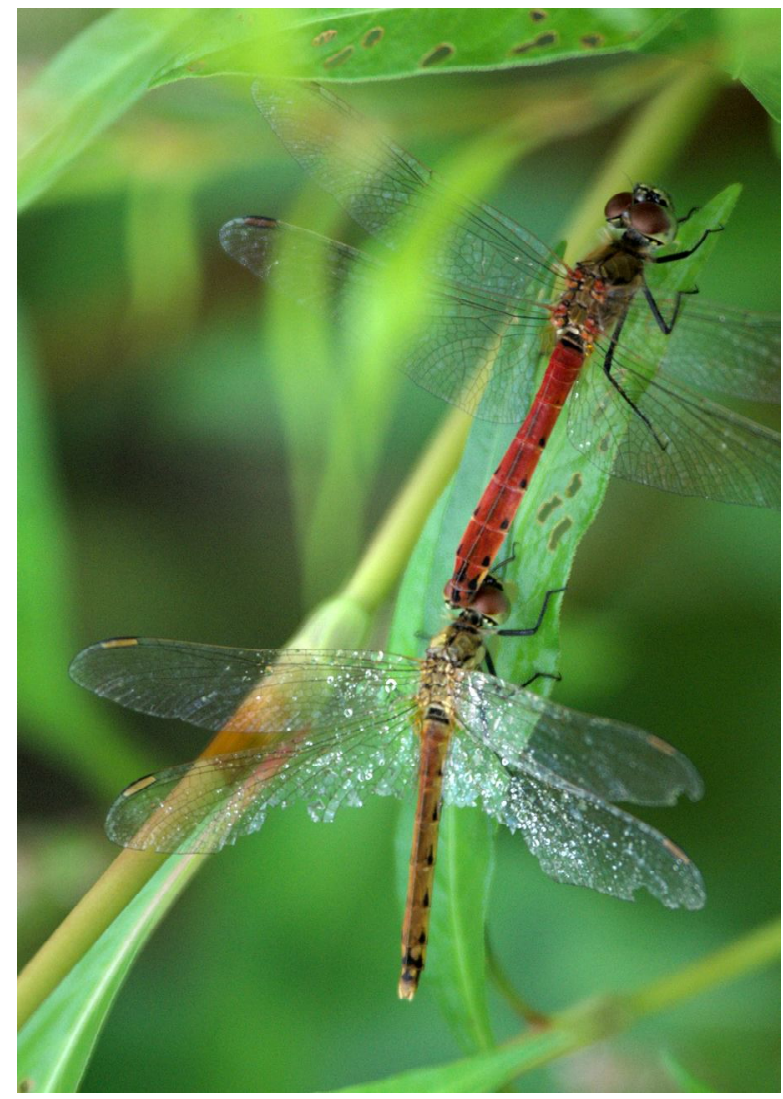

Fig. 3. Tandem of Sympetrum depressiusculum at the Obskoe Water Reserve SE bank at the Glukhaya Rivulet estuary, Ordynskoe District, Novosibirskaya Oblast, 14.08.2020; photo by P. Komkov (https://www.inaturalist.org/observations/57228233; public domain).

Рис. 3. Тандем Sympetrum depressiusculum на Обском водохранилище, А. Глухая, Ордынский р-н, Новосибирская обм., 14.08.2020; фото П. Комкова (https:// www.inaturalist.org/observations/57228233).
(91592753); the same place and date, $54.1477^{\circ} \mathrm{N}, 81.6118^{\circ} \mathrm{E}$, 5.08.2020, O. Kosterin - 1 ㅇ (teneral), 1 tandem (91591820, 91592501); the same place and date, $54.1477^{\circ} \mathrm{N}, 81.6119^{\circ} \mathrm{E}$, O. Kosterin - $20^{7} 0^{7}$ (1 immature, 1 mature), 19 (mature) (91592353, 91592354, 91593285); the same place and date, $54.1479^{\circ} \mathrm{N}, 81.6119^{\circ} \mathrm{E}$, O. Kosterin - $10^{\top}$ (immature) (91592352); the same place and date, $54.1475^{\circ} \mathrm{N}, 81.6116^{\circ} \mathrm{E}$ V. Kosterin - $10^{7}$ (mature); $54.1475^{\circ} \mathrm{N}, 81.6117^{\circ} \mathrm{E}$, V. Kosterin - $10^{\top}$ (teneral), 2 우 (1 teneral, 1 immature) (90038542; 90041164; 90041189); the same place and date, (90038542); the same place and date $54.1475^{\circ} \mathrm{N}, 81.6118^{\circ} \mathrm{E}$, V. Kosterin - 10 (immature) (90041168); the same place and date, $54.1476^{\circ} \mathrm{N}, 81.6116^{\circ} \mathrm{E}, \mathrm{V}$. Kosterin - 2 우 (teneral) $(90038537,90038539)$; the same place and date, $54.148^{\circ} \mathrm{N}$, $81.612^{\circ} \mathrm{E}$ (observations by these author were geotagged manually rather than a GPS device), T. Kolesnikova $-50^{7} \sigma^{7}$ ( 2 teneral, 2 immature, 1 mature), 4 우 ( 2 teneral, 2 immature), 1 tandem (90116267, 90116268, 90116474, 90116562, 90169365, 90170210, 90170212, 90170215, 90170567, 90170983). Novosibirskaya Oblast, Novosibirsk, Academy Town environs, the Obskoe Water Reserve E bank, the Zyryanka Rivulet estuary, $54.8194^{\circ} \mathrm{N}, 83.0848^{\circ} \mathrm{E}, 21.08 .2020$, O. Kosterin - 10 (immature) (91961373); the same place and date, $54.8192^{\circ} \mathrm{N}, 83.0854^{\circ} \mathrm{E}, \mathrm{O}$. Kosterin $-10^{\top}$ (immature, 19 (mature) $(91964968,91966740)$; the same place and date, $54.8193^{\circ} \mathrm{N}, 83.0848^{\circ} \mathrm{E}, \mathrm{O}$. Kosterin - 1 우 (teneral) (91970849); the same place and date, $54.8193^{\circ} \mathrm{N}, 83.0853^{\circ} \mathrm{E}$, O. Kosterin 1 (immature) (91968109); the same place and date, $54.8192^{\circ} \mathrm{N}, 83.0855^{\circ} \mathrm{E}, \quad \mathrm{O}$. Kosterin - 2 우 (immature) (91967599, 91968821$) ; 54.8192^{\circ} \mathrm{N}, 83.0854^{\circ} \mathrm{E}, \mathrm{O}$. Kosterin $10^{7}$ (mature), 19 (teneral) (91969912, 91970561); the same place and date, $54.8191^{\circ} \mathrm{N}, 83.0852^{\circ} \mathrm{E}$, O. Kosterin - $10^{7}$ (immature) (91962868); the same place and date, $54.8191^{\circ} \mathrm{N}$, $83.0854^{\circ}$ E, O. Kosterin - $10^{\top}$ (mature) (91967482)

Remarks. Identification of this species is unmistakable even by photos in both sexes due to distinct paired black marks at posteriolateral corners of abdominal segments (which are somewhat expanded), indented from their lateral margins. All females had a slight ochre-yellow tint over their wing membranes. Also a peculiar cue for the species' identification in flight is an impression that the end of the abdomen is slightly bent down.

Observations. According to the first observer of this species in Novosibirskaya Oblast, Pavel Komkov (pers. comm.) and his precise geotagging, the species was first met in mid-August 2020 at a swampy estuary the Glukhaya Rivulet, where it enters the Obskoe Water Reserve after flowing through pine forest at its quite elevated SE bank. The estuary was bordered and nearly isolated from the main reserve with a sandy spit, had a sandy bottom and very shallow water, from which rather sparse reed (Phragmites australis (Cav.) Trin. ex Steud.) thickets emerged.

This quite peculiar habitat type is frequent along the reservoir banks. This inspired further search next year, and indeed, on 21.08.2021, a couple of dozens of individuals of $S$. depressiusculum, mostly males, were found by the first author at the same right bank of the Reservoir at a similar estuary of a small rivulet, Zyryanka, already in Novosibirsk City limits near Academy Town, $66 \mathrm{~km} \mathrm{NE}$ of the previous locality. The estuary had stagnant shallow water tightly filled with rotting pine logs, with the banks overgrown with sedge and some reed patches and partly surrounded by poplar and aspen stand. Most individuals were immature and some teneral, obviously emerged in the morning of that day, but few mature males and females with bright-red abdomen were also present. They were accompanied by more numerous Sympetrum pedemontanum pedemontanum (Müller in Allioni, 1766), with similar age spectrum, few mature males of $S$. sanguineum, $S$. flaveolum and one female of $S$. vulgatum 


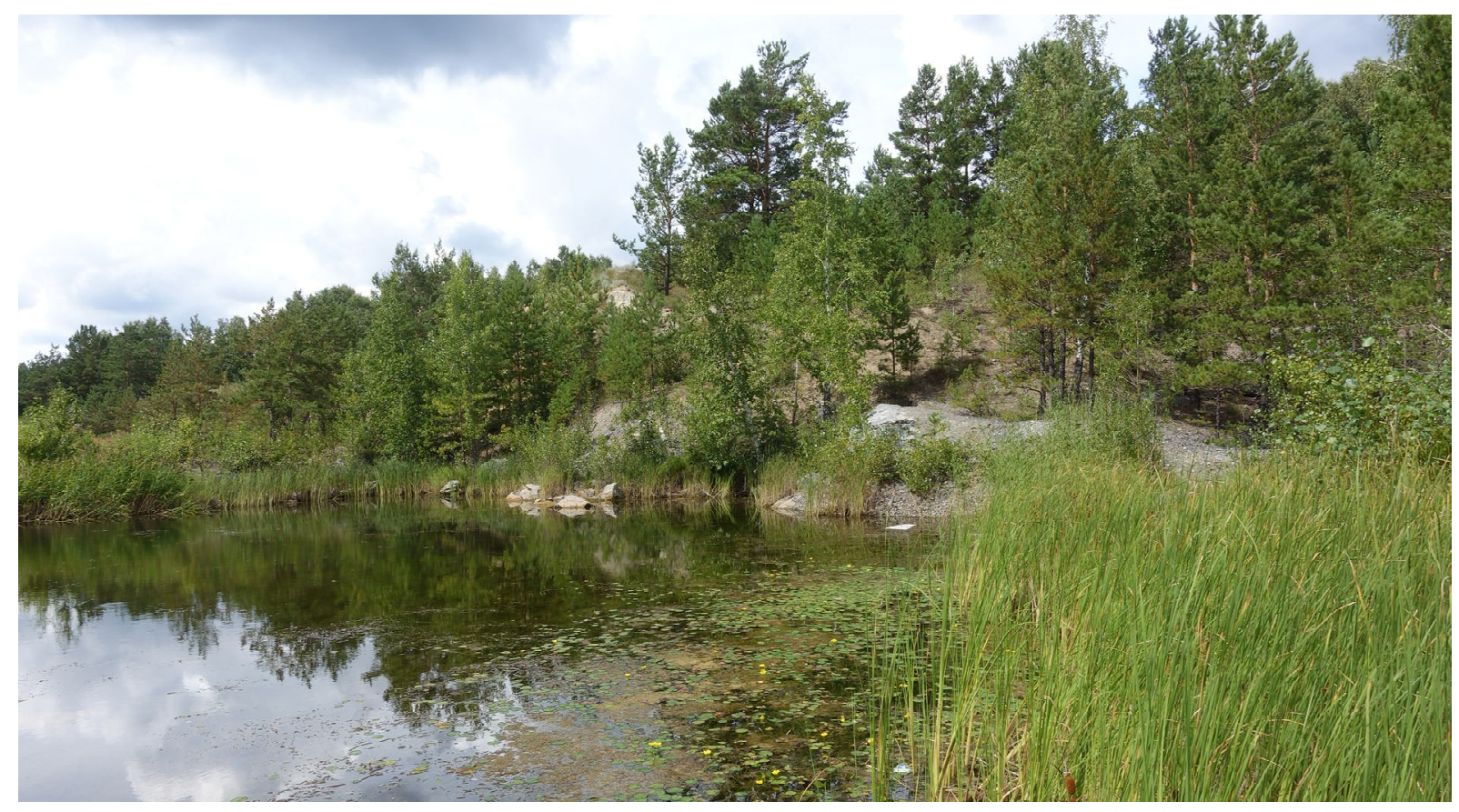

Fig. 4. A pool in the former stone pit on the Obskoe Water Reserve NW bank $1.1 \mathrm{~km} \mathrm{NE}$ of Spirino village outskirts, where Sympetrum depressiusculum breeds in abundance, Ordynskoe District, Novosibirskaya Oblast, 5.08.2021; photo by O. Kosterin.

Рис. 4. Водоем в заброшенном каменном карьере на С3 берегу Обского водохранилиша 1,1 км СВ окраины с. Спирино, на котором в изобилии развивается Sympetrum depressiusculum, Ордынский р-н, Новосибирская область, 5.08.2021; фото О. Костерина.

vulgatum; also solitary males of Aeshna grandis (Linnaeus, 1758 ) and $A$. mixta flew above the water. S. depressiusculum kept to grassy patches and sedge by the banks and perched on sedge or other grasses, herbs or bushes but never on logs, as males of other species of the same genus frequently did.

In the same year, $S$. depressusculum was also found en masse at the opposite, left bank of the Obskoe Water Reserve $120 \mathrm{~km} \mathrm{SW}$ of the above considered locality, in quite a peculiar habitat. These were two twin knee-deep pools in an abandoned stone quarry situated at the reservoir bank and bordered by vast pine forest on rocks (Fig. 4). The pools were warm, rimmed with a stand of gracefull cattail (Typha laxmannii Lepech.) and patches of reed, near which the surface was covered with floating heart (Nymphoides peltata (S.G. Gmel) Kuntze); the water was filled with Chara contraria A.Braun ex Kützing. They abounded with marsh frogs (Pelophylax ridibundus (Pallas, 1771), an invasive species in Siberia) and grass snakes (Natrix natrix (Linnaeus, 1758)). Other 11 Odonata species registered at that habitat on the day of its examination were Calopteryx splendens splendens (Harris, 1780) (a single male), Lestes sponsa (Hansemann, 1823) (abundant), Sympecma paedisca (Brauer, 1877) (many young individuals), C pulchellum sibiricum Belyshev, 1964, Enallagma cyathigerum risi Schmidt, 1961, Aeshna affinis Vander Linden, 1820 (many territorial males, some females), A. grandis (several, mostly females), Libellula quadrimaculata Linnaeus, 1758 (an old female ovipositing), Sympetrum danae (few mature males and an immature female, $S$. vulgatum vulgatum (a teneral female, a mature and an immature male), $S$. pedemontanum pedemontanum (a single mature male). Besides, on 23.07.2021, T. Kolesnikova has registered there a male of Leucorrhinia albifrons (Burmeister, 1839) (iNaturalist observation 88403828).

\section{Discussion}

Until 2020, no reliable evidence of the presence O. brunneum in Siberia were known. The only existing report was by Hagen [1856] for Irkutsk, with no further detail. Its inclusion for South Siberia our Russian Checlklist [Malikova, Kosterin, 2019] with a note 'hot springs only' was an unjustified extrapolation from such occurrence of $O$. albistylum (Selys, 1848); actually an error). However, in June 2020 the O. brunneum was quite expectedly found by Sergey Borisov [2021] in Lokot' District of Altaiskiy Kray, the southernmost point of Siberia at the border with Kazakhstan, from where this species was reported as widespread and common [Chaplina et al., 2007]. That locality was at $51^{\circ} \mathrm{N}$, that is $4^{\circ}$ or $430 \mathrm{~km}$ to the south of Novosibirsk. So, the Novosibirsk population appears to be an intriguing isolate, of an uncertain age. However, the absence of other lotic odonate species at that site may provide a clue for explanation of its existence. Although Zayel'stovskiy Park is actually a very big $(10 \times 5 \mathrm{~km})$ area of moderately or scarcely disturbed natural habitats (mostly pine forest), the Elts'ovka $2^{\text {nd }}$ Rivulet enters it after having crossed for $9 \mathrm{~km}$ a densely populated and industrial area of Novosibirsk downtown, namely Zayeltsovskiy and Kalininskiy Districts. That means that the rivulet is heavily polluted and so cannot be inhabited by most lotic species of Odonata sensitive to water quality, while $O$. brunneum is quite pollution-prone. At the same time, its water most probably somewhat warmer, especially in 

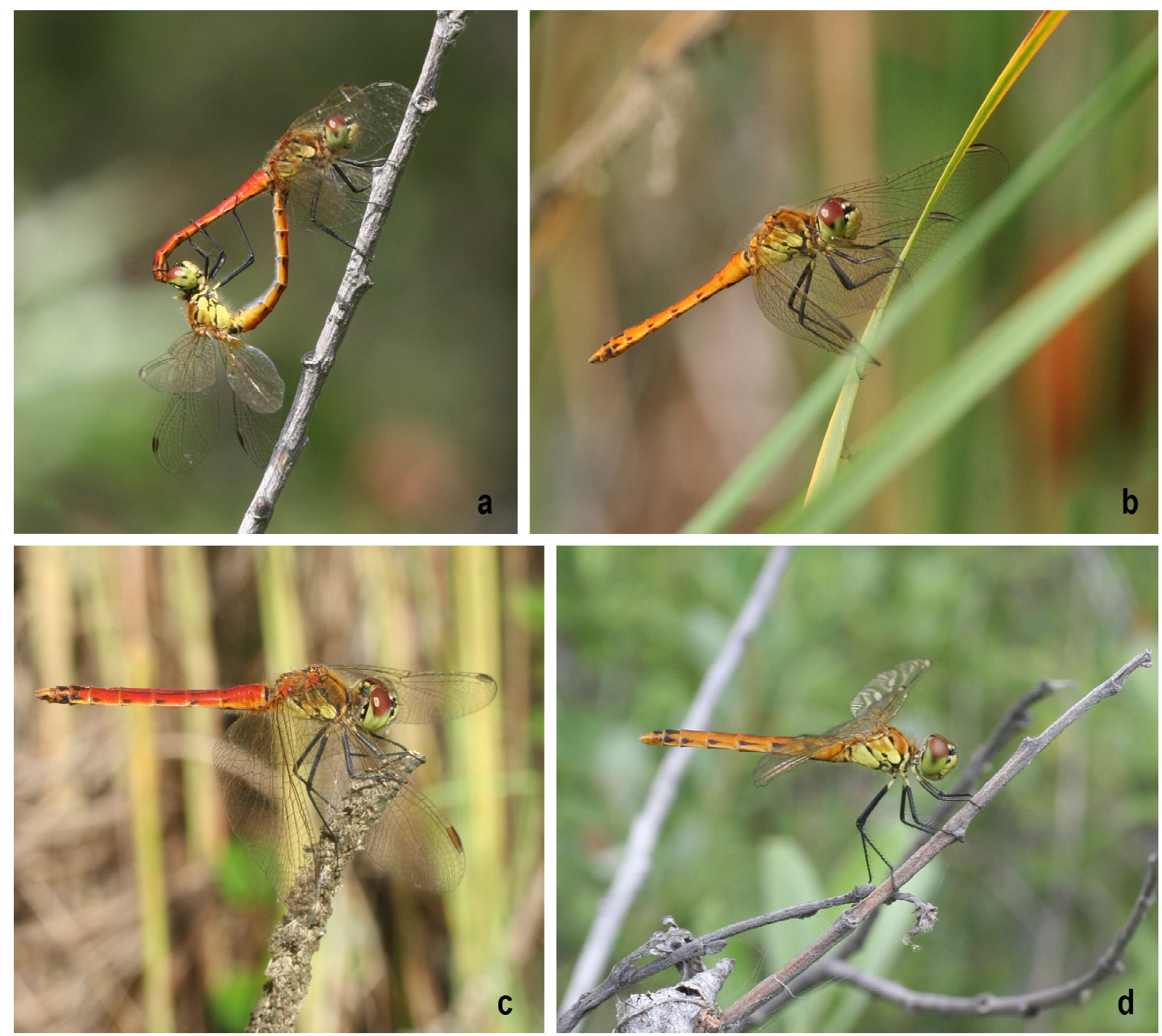

Fig. 5. Sympetrum depressiusculum at the pool $1.1 \mathrm{~km} \mathrm{NE}$ of Spirino (Fig. 4), Ordynskoe District, Novosibirskaya Oblast, 5.08.2021; photo by O. Kosterin: a - copula; b - immature male; c - mature male; $d$ - teneral female; photo by O. Kosterin.

Pис. 5. Sympetrum depressiusculum на водоёме 1,1 км СВ с. Спирино (Рис. 4), Ордынский район, Новосибирская область, 5.08.2021; a - копула; b - молодой самец; с - зрелый самец; d - свежевыплодившаяся самка; фото О. Костерина.

winter, than natural streams at this latitude. This made possible fir some occasional stray of O. brunneum to successfully colonise this restricted habitat. «In the north of its range it is often a pioneer species and appears promptly at new, often man-made, warm habitats, declining or even disappearing as the vegetation develops» [Kalkman, Ambrus, 2015: 277].

So far, $S$. depressiusculum was known only from three regions of South Siberia: Central Tuvinian Depression, Minusinsk Depression, and southern Transbaikalia (Dauria; with many records there) [Belyshev, 1973; Kosterin, 2004; Kosterin, Zaika, 2010]]. This is the first record of the species in West Siberia and the northernmost (54.82 N) in Siberia. Curiously, it was hitherto found only at the Obskoe Reservoir banks faced by vast pine forests. This is a fairly late species in the region, starting to emerge not earlier than the last days of July (since it was not yet found the same locality at Spirino when examined by T. Kolesnkkova on 23.07.2021) and still emerging in late August.

These two findings result from one year of existence the project «Dragonflies of Russia» at iNaturalist (2021) and so illustrate the importance and power of citizen science and centralised platforms accumulating geotagged biodiversity data from public, of course only for groups of organisms easily identifiable by appearance, such as dragonflies.

For a state of the art reference, here we provide the list of 57 species currently known from Novosibirskaya Oblast: Calopteryx splendens splendens (Harris, 1780), Lestes barbarus (Fabricius, 1798), L. dryas Kirby, 1890, L. macrostigma (Eversmann, 1836), L. sponsa (Hansemann, 1823), L. virens vestalis Rambur, 1842, Sympecma paedisca (Brauer, 1877), Coenagrion 
armatum (Charpentier, 1840), C. ecornutum (Selys, 1872), C. hastulatum (Charpentier, 1825), C. johanssoni (Wallengren, 1894), C. lunulatum (Charpentier, 1840), C. puella (Linnaeus, 1758), C pulchellum sibiricum Belyshev, 1964, Erythromma najas najas (Hansemann, 1823), Enallagma cyathigerum risi Schmidt, 1961, Ischnura elegans (Vander Linden, 1820), I. pumilio (Charpentier, 1825), Nehalennia speciosa (Charpentier, 1840), Platycnemis pennipes (Pallas, 1771), Aeshna affinis Vander Linden, 1820, A. caerulea (Ström, 1783), A. crenata Hagen, 1856, A. grandis (Linnaeus, 1758), A. juncea (Linnaeus, 1758), A. mixta Latreille, 1805, A. serrata Hagen, 1856, A. subarctica Walker, 1908, A. viridis Eversmann, 1836, Gomphus vulgatissimus (Linnaeus, 1758), Shaogomphus postocularis epophthalmus (Selys, 1872), Stylurus flavipes (Charpentier, 1825), Nihonogomphus ruptus (Selys et Hagen, 1858), Ophiogomphus cecilia (Geoffroy in Fourcroy, 1785), Cordulia aenea aenea (Linnaeus, 1758), Epitheca bimaculata (Charpentier, 1825), Somatochlora arctica (Zetterstedt, 1840), S. exuberata Bartenev, 1910, S. flavomaculata (Vander Linden, 1825), S. metallica (Vander Linden, 1825), Macromia amphigena fraenata Martin, 1907, Leucorrhinia albifrons (Burmeister, 1839), L. caudalis (Charpentier, 1840), L. dubia (Vander Linden, 1825), L. pectoralis (Charpentier, 1825), L. rubicunda (Linnaeus, 1758), Libellula quadrimaculata Linnaeus, 1758, Orthetrum brunneum (Fonscolombe, 1837), O. cancellatum (Linnaeus, 1758), Sympetrum croceolum (Selys, 1883), S. danae (Sulzer, 1776), S. depressiusculum (Selys, 1841), S. flaveolum (Linnaeus, 1758), S. fonscolombii (Selys, 1840), S. pedemontanum pedemontanum (Müller in Allioni, 1766), S. sanguineum (Müller, 1764), S. vulgatum vulgatum (Linnaeus, 1758). Of these species, only A. caerulea and $S$. fonscolombii have not been recorded in Novosibirsk City limits (L. barbarus was at last found there at the Zyryanka Rivulet mouth on 26.08.2021, observation 93025360), and anywhere in the part of the Province easterly of the $\mathrm{Ob}$ ' River, having a gentle hilly relief in contrast to the larger, perfectly flat western part (impoverished with lotic species), the fauna of which is still insufficiently studied.

The expected taxa to be looked for in Novosibirskaya Oblast as found in neighbouring provinces are Coenagrion glaciale (Selys, 1872) (in the Ob' River valley), Enallagma cyathigerum cyathigerum (Charpentier, 1840) (in the north), Anax parthenope (Selys, 1839) (in the south), Ophiogomphus obscurus Bartenev, 1909 (in Salairskiy Kryazh range and Bolotnoe District), Sympetrum meridionale (Selys, 1841) (in the south).

According to personal observations by Sergey L. Nikolaev, in late May of some year in the interval 1963 1965 he observed mass invasion of Novosibirsk with numerous individuals of Libellula depressa Linnaeus, 1758 which lasted for few days only. The collected species were lost and the species has never been reported for Novosibirskaya Oblast. However, the species is easily recognisable, recently it has been found in Altaiskiy Kray [Kosterin, Gribkov, 2019], another spe- cies of the same genus, L. quadrimaculata, is famous for its far mass migrations [Popova, Haritonov, 2010]. It is not excluded that this event has taken place indeed and similar invasions are not excluded in future.

\section{Acknowledgements}

The work of the first author was partly supported Russian State Scientific Project 0259-2021-0016. The authors are grateful to Pavel Komkov and Sergey Nikolaev for information and to Tatyana Kolesnikova for revealing the habitat of $S$. depressiusculum.

\section{References}

Belyshev B.F. 1973. Dragonflies (Odonata) of Siberia. Vol.1. Part 2. Novosibirsk: Nauka, Siberian Division. 620 p. [In Russian, with English title].

Borisov S.N. 2005. Aperiodic changes in number of Lestes macrostigma (Eversmann, 1836) (Odonata, Lestidae) in forest-steppe of West Siberia // Evraziatskii Entomologicheskii Zhurnal. Vol.4. No.1. P.30-32.[In Russian, with English summary].

Borisov S.N. 2021. Updates to the fauna of dragonflies (Odonata) of the Altaiskii Krai with new records of species for Siberia // Evraziatskii Entomologicheskii Zhurnal. Vol.20. No.3. P.136-141.

Borisov S.N., Popova O.N., Haritonov A.Yu. 2012. [Dragonflies] // Ravkin Y.S. (Ed.) Bioraznoobrazie Karasuksko-Burlinskogo regiona (Zapadnaya Sibir'). Novosibirsk: Izdatel'stvo Sibirskogo otdeleniya RAN. P.135-148. [In Russian].

Chaplina I.A., Dumont H.J., Haritonov A.Y., Popova O.N. 2007. A review of the Odonata of Kazakhstan // Odonatologica. Vol.36. No.4. P.349-364.

Dragonflies of Russia (2021) Internet resource. https:// www.inaturalist.org/projects/strekozy-rossii-odonata-ofrussia. Accessed on 30.08.2021.

Hagen H.A. 1856. Die Odonaten-Fauna des Russischen Reichs // Stettiner entomologische Zeitung. Bd.17. S.363-380

Haritonov A.Yu. 2010. A dedication to Boris Fedorovich Belyshev on his $100^{\text {th }}$ birthday: retrospective and perspectives of odonatology in Siberia // Evraziatskii Entomologicheskii Zhurnal. Vol.9. No.2. P.223-230. [In Russian, with English summary].

Haritonov A.Yu., Borisov S.N., Popova O.N. 2007. Odonatological researches in Russia // Evraziatskii Entomologicheskii Zhurnal. Vol.6. No.2. P.143-156. [In Russian, with English summary].

iNaturalist, 2021. Internet resource. https://www.inaturalist.org. Accessed on 30.08.2021.

Kalkman V., Ambrus A. 2015. Orthetrum brunneum (Fonscolombe, 1837) // Boudot J.-P., Kalkman V.J. (Eds) Atlas of the European dragonflies and damselflies. The Netherlands: KNNNV Publishing. P.275-276.

Kosterin O.E. 2004. Odonata of the Daurskii State Nature Reserve area, Transbaikalia, Russia // Odonatologica. Vol.33. No.1. P.41-71.

Kosterin O.E. 2007. Dragonflies (Insecta, Odonata) of Akademgorodok // Zhimulev I.F. (Ed.) Priroda Akademgorodka: 50 years later on]. Novosibirsk: SO RAN Publishing House. P.74-91. [In Russian, with English summary].

Kosterin O.E. 2013. [New data on dragonflies and damselflies (Odonata) of Akademgorodok and its surroundings.] // Zhimulev I.F. (Ed.) (Dynamics of Ecosystems of Novosibirsk Academy Town]. Novosibirsk: SO RAN Press. P.204-209. [In Russian].

Kosterin O.E. 2015. On the Odonata of North Kazakhstan Province. I. First data on Petropavlovsk // International Dragonfly Fund Report. Vol.86. P.1-26. 
Kosterin O.E. 2020. [Fauna of dragonflies (Odonata) and butterflies (Lepidoptera: Papilionoidea) of the Shlyuzovskoy forest-bog complex] // Mironycheva-Tokareva I.N. (Ed.) [Unique Nature Monument, «Skazochnyy» Shlyuzovskoy Forest-Bog Complex. Ecology and Protection. Materials of the regional scientific-practical conference, 19 ${ }^{\text {th }}$ April 2018]. Novosibirsk: Okarina. P.78-88. [In Russian].

Kosterin O.E., Gribkov A.V. 2019. The first record of Libellula depressa Linnaeus, 1758 (Odonata: Libellulidae) in Siberia, Russia // Acta Biologica Sibirica. Vol.5. No.2. P.30-32.

Kosterin O.E., Haritonov A.Y., Inoue K. 2001. Dragonflies of the part of Novosibirsk Province east of the Ob', Russia // Sympetrum Hyogo. Vol.7/8. P.24-49. [In English and Japanese].

Kosterin O.E., Zaika V.V. 2010. Odonata of Tuva, Russia // International Journal of Odonatology. Vol.13. P.277-328.

Malikova E.I., Kosterin O.E. 2019. Check-list of Odonata of the Russian Federation // Odonatologica. Vol.48. No.1/2. P.4978 .

Popova O.N., Eremina E.E. 2016. Sympetrum fonscolombi (Selys, 1840) (Odonata: Libellulidae) in northernmost areal localities in Chelyabinskaya and Novosibirskaya Oblast's of Russia // Evraziatskii Entomologicheskii Zhurnal. Vol.15. No.1. P.45-59. [In Russian, with English summary].

Popova O.N., Haritonov A.Yu. 2010. Population dynamics and migration in the dragonfly Libellula quadrimaculata L., 1788 (Odonata: Libellulidae) // Evraziatskii Entomologicheskii Zhurnal. Vol.9. No.2. P.231-238. [In Russian, with English summary].

Popova O.N., Haritonov A.Y. 2012. On the change of the ranges of certain dragonfly (Odonata) species of the Russian fauna. // Proceedings of the Russian Entomological Society. St.Petersburg. Vol.83. No.1. P.73-82. [In Russian, with English summary].

Ueda K. 2021. iNaturalist Research-grade Observations. iNaturalist.org. Occurrence dataset. Internet resource https:/ /doi.org/10.15468/ab3s5x. Accessed on 30.08.2021

Zaika V.V. 1974. [Fauna of Dragonflies (Odonata) of the northern part of Kulundinskaya Steppe] // Voprosy entomologii Sibiri. Novosibirsk: Nauka, Siberian Division. P.43-44. [In Russian]. 